\title{
MOOC in the Inverted CLIL Approach: Hybridizing English
}

\section{Teaching/Learning}

\author{
Kyria R. Finardi ${ }^{1 *}$, Nádia Silveira ${ }^{2}$, Sebastião Lima ${ }^{3} \&$ Ana Rachel Mendes ${ }^{3}$ \\ ${ }^{1}$ Department of Languages, Culture and Education, Federal University of Espirito Santo, Vitoria, Brazil \\ ${ }^{2}$ EAMES, Vitoria, Brazil \\ ${ }^{3}$ PPGEL/UFES, Vitoria, Brazil \\ * Kyria R. Finardi, E-mail: kyria.finardi@gmail.com
}

Received: October 9, 2016

Accepted: October 19, 2016

Online Published: October 24, 2016

doi:10.22158/selt.v4n4p473

URL: http://dx.doi.org/10.22158/selt.v4n4p473

\begin{abstract}
The current digital society requires new approaches to the teaching of English as an Additional Language (EAL). This paper aims at proposing a combination of current blended approaches for the teaching of EAL. It describes a set of activities for an EAL blended course by adopting a Content and Language Integrated Learning approach (CLIL) through an Inverted Classroom approach (IC), alias Inverted CLIL (Finardi, 2015) with the use of a MOOC. It is believed that the integration of a MOOC through an Inverted CLIL approach to EAL may lead to meaningful language and content learning. In addition, it may contribute to the development of students' autonomy, critical thinking and communication skills.
\end{abstract}

\section{Keywords}

CLIL, inverted classroom, inverted CLIL, English teaching, blended approaches

\section{Introduction}

In the digital society we live in, several changes brought about by globalization and cultural hybridism — such as time and space compression and regular contact among cultures, identities and discourses - have allowed new ways of thinking, interacting and living. Castells (1999) points out that, in the network society, minds work through innumerous connections and flow simultaneously in several directions instead of moving in a linear and typographic way as in pre-digital era. In addition, Lankshear and Knobel (2003) refer to these new ways of thinking as "digital epistemologies" which can be fostered by knowledge transdisciplinarity and performativity. Also, Levy (1999) suggests that in the information society, Information and Communication Technologies (ICTs), especially the internet, allows a faster and more democratic flow of information, products and services. Resultantly, new literacies, values and perspectives arise along with new social practices in digital settings. 
Education has been particularly affected by the way internet has altered teachers' and students' roles in the classroom. On the one hand, students are promptly provided with a great number of tools and contents beyond teachers' capacity. On the other hand, they still need teachers' guidance and mediation on how to use and filter all the information given by the internet (Bohn, 2013). One of the biggest innovation this new era has brought about is the major role form plays in education. The way a message is conveyed has become more important than the message content itself and it determines how it is going to be received and reacted to (Bohn, 2013). As a result, multimodality has become a key feature in today's communication and should be sought after by educators as well (Monte Mór, 2012).

This paper is mainly focused in the significant impact these changes have had in education in general and in English Language Teaching (ELT) in particular. Regarding the latter, one impact has been in the status of English often seen as a global or international language (Finardi, 2014). Despite controversies and inquiries, in many ways English has been considered the language of technology, science and communication. Therefore, being able to communicate in English is key to having access to information and learning opportunities provided by ICTs, which are mainly available in this language (Finardi, Prebianca, \& Momm, 2013; Finardi \& Tyler, 2015). Moreover, English language can contribute to social inclusion as it favors academic mobilization (Finardi \& Archanjo, 2015), circulation of academic production (Finardi \& França, 2016) and integration of immigrants and refugees (Ortiz \& Finardi, 2015). Finardi, Prebianca and Momm (2013) suggest that the development of English proficiency along with the development of digital literacy skills are paramount for the establishment of social capital (Warschauer, 2003). Thus, it can be said that there are new motivations and demands for English as an Additional Language (EAL) (Jordão, 2014) learning.

Besides the affordances of English to social inclusion through the expansion of access to information, another important innovation in ELT are the digital tools that can be used for language development. Cellphone and computer applications, software, websites and even social network sites (e.g., Facebook, in Finardi \& Porcino, 2016) present meaningful EAL learning opportunities. However, ICTs and its pedagogical possibilities are unknown, disregarded and even feared by many EAL teachers. So as to contribute to the incorporation of ICTs in teachers' practices and to the reshaping of ELT in the digital era with a more meaningful EAL approach, this paper describes some recent and relevant approaches to the teaching of English as an additional language in what follows.

\section{Recent Approaches to ELT}

The term blended or hybrid approaches have been used in different contexts and for various purposes. In this study, it is referred to as the combination between online and traditional face-to-face teaching (Graham, 2006). In the past, both learning environments were taken into account separately for having different methods and target audience. Traditional face-to-face teaching was known as having teacher as a guide and synchronous interaction among participants whereas in online teaching, the student determines the rhythm and interaction usually happens asynchronously. Nevertheless, with ICTs 
innovations in learning possibilities in the online environment have reached new dimensions and blurred the border between online and traditional classrooms by allowing faster responses and new ways to interact (Graham, 2006).

In blended approaches, there are many variations in terms of learning time spent online or face-to-face (Graham, Allen, \& Ure, 2005). Also, it can be implemented at the activity, course, program or institution level (Graham, 2006). Regardless of the implementation level chosen, as blended learning planning takes place, it is necessary to carefully take into account the best and worst aspects of each environment in order to properly address the goals and particularities of each group. When these matters are observed, blended learning can mean an increase in learning convenience and access, cost and pedagogy effectiveness (Graham, Allen, \& Ure, 2005).

In EAL teaching, blended approaches have become a trend mainly because it gives students opportunities to interact more meaningfully in the target language (Finardi \& Porcino, 2014). Also, they may be used as a relevant tool for social and digital inclusion as well as for digital literacy development (Prebianca, Cardoso, \& Finardi, 2014). In addition, combining both environments can foster collaboration and give greater value to students' previous knowledge, having students, their needs, culture and social context as focus of the hybrid learning experience (Leffa, 2012). However, given the fact that hybridizing ELT has been discussed only recently, there are still many debates on the functionality of it and whether it can be substantially implemented.

\subsection{Inverted Classroom}

A new attempt to reshape ELT according to current trends in the digital society is the use of Flipped or Inverted Classroom (IC) approach. This blended approach aims at filling in the gap between divergent teaching and learning styles by reversing learning environments: instruction that usually happens in the classroom is done at home and activities that are usually assigned as homework take place in the classroom. This way, students may show more motivation and better performance as learning experiences are offered in different learning styles (Lage, Platt, \& Treglia, 2000).

In ELT, some researchers have found evidence of positive results in the use of IC (Finardi, Prebianca, \& Schmitt, 2016). For example, through the use of blended activities, Silveira and Finardi (2015) have implemented IC to an intact English classroom and its results suggest that the combination of pedagogical tasks with online tools contributed to the development of learners' autonomy, language skills and digital literacy.

\section{$2.2 \mathrm{MOOCs}$}

Another of the many new learning possibilities allowed by the ICTs are the Massive Open Online Courses (MOOCs), which have emerged in order to enlarge access to education. MOOCs aim at delivering free quality education to a great number of people. Universities and platforms have developed a partnership in which they offer several courses on various topics allowing for asynchronous interaction among professors, tutors and students. Notwithstanding, the access is still limited mainly to English speakers as the majority of the courses seem to be offered only in English (Finardi \& Tyler, 2015). The 
reason for that can be that great part of the universities that have been engaging in this trend belong to English-speaking countries or that have adopted an English Medium Instruction. For this reason, this paper suggests that MOOCs should be used as part of blended approaches in order to teach English through content learning.

2.3 CLIL

Content and Language Integrated Learning (CLIL) is another current trend in ELT which aims at teaching several contents through a specific language or vice-versa (Coyle, Hood, \& Marsh, 2010). This approach has been widely used in many parts of the world, especially in Europe and Canada, mainly in bilingual schools. In CLIL, either language or content can be more emphasized depending on the goals proposed by the teacher. For example, Finardi, Silveira and Alencar (2016) conducted a case-study in Brazil that aimed at preparing, implementing and analyzing a program using CLIL in order to teach the contents of First Aid and Waves in English for a Brazilian Navy Boarding School. Their findings suggest that CLIL may have a positive reaction from participants, especially in the teaching of more simple contents. On the other hand, CLIL projects must be carefully prepared and implemented, taking into account content complexity and participants' language proficiency level. When used to teach subjects related to Civic Education in French as a foreign language in Switzerland (Ortiz \& Finardi, 2015), CLIL showed good results in participants and contributed to social inclusion. Although CLIL does not imply the use of ICTs, MOOCs, podcasts, social networks, blogs, webquests and other tools may be incorporated in it (Ortiz \& Finardi, 2015; Finardi, 2015).

\subsection{Inverted CLIL}

Considering both approaches - the IC and the CLIL — a new blended approach was proposed by Finardi (2015) and coined the Inverted CLIL approach. By hybridizing IC and CLIL aspects, the Inverted CLIL approach may present the following implications: better respect for students learning styles and rhythm; better use of the target-language; education beyond the physical limits of schools; engagement of students in a more active and autonomous learning; reinforcement of language skills through content learning and vice-versa; alignment with current demands of the technology society; motivation of reflection through transdisciplinarity and flow among contents, language and technology (Finardi, 2015). So as to reflect about the possibilities and limitations of the Inverted CLIL approach, and contribute to teacher informed decisions, the present study proposes a set of activities and teaching plans following the Inverted CLIL approach through the combination of pedagogical tasks, MOOCs and online activities.

\section{MOOC in the Inverted CLIL Approach: Teaching Proposal for Sustainability and English and}

\section{Vice-Versa}

As a means of analyzing the potential and limitations of the Inverted CLIL Approach, a teaching proposal based on the Inverted CLIL approach was elaborated in this study, following suggestions of Finardi (2015) related to the theme and the use of MOOC. The elaborated teaching proposal aims at teaching the content of sustainability in English as an additional language using a MOOC available in the Coursera 
(Note 1) platform and adapted to the Inverted CLIL Approach.

According to the Coursera platform, the MOOC "Introduction to Sustainability" (Note 2) has the purpose of introducing an academic approach to sustainability exploring how human societies can survive in the face of global change, ecosystem degradation and resource limitations. The course emphasizes important knowledge areas of theory and practice of sustainability, including population, ecosystems, global change, energy, agriculture, water, environmental economy and policy, ethics and cultural history. The course is taught in English with subtitles in English, Portuguese, Vietnamese, Spanish and Chinese.

The proposal of the pedagogical sequence elaborated in this study and called 'Sustainability in English', is ideal for learners with an intermediate level of language proficiency, or for high school learners, once the subject is very actual, presenting relevant information for the accomplishment of the high school national exam in Brazil, the ENEM (Note 3) test. It is important to reiterate that learners should have a certain level of proficiency so that they may benefit from the CLIL Approach (Alencar, 2016) and to reinforce the fact that the use of the mother tongue in class may serve as a way of lexical disambiguation, though most of the instruction should be delivered by means of the additional language (Lasagabaster, 2013). The content of the proposed theme is related to themes in Federal Institutes in Brazil, such as the Biotechnology, Agroindustry and the Environment Technical Courses there.

To present the pedagogical sequence clearly, the activities will be described in a sequential order, according to the strategies of each face-to-face class and the events to be held outside the class, following the model of the Inverted CLIL Approach. The teaching proposal includes seven face-to-face classes of one hour each, and an amount of two-hour activities to be done extra class prepared by the teacher whereby the MOOC will be used to deliver the content, which is interspersed with the language in the activities done in class and at home.

According to the Coursera platform, the course "Introduction to Sustainability" has a total of eighty hours divided into activities such as watching videos, answering questionnaires and doing tests. The course is divided into eight parts, namely: 1) Orientation and Introduction, 2) Population, 3) Ecosystems and Climate Change, 4) Energy, 5) Water and Agriculture, 6) Environmental Policy, 7) Measuring Sustainability, and 8) Conclusion. The pedagogical sequence elaborated in this study should be implemented in a school semester or roughly four months (one school semester), with a workload of seven hours of face-to-face classes, two hours of extra class activities, besides four weekly hours dedicated to the MOOC content, with a total of seventy-three hours. The chosen MOOC provides the option of deactivating the deadline for posting activities, facilitating the teaching proposal implementation, once the teacher can establish the deadline of the activities related to each part of the course in accordance with their planning in the school semester and in the context where they teach.

Before learners are exposed to the MOOC "Introduction to Sustainability", the teacher should dedicate the three first classes - besides the workload of extra class activities - to the accomplishment of the activities to develop the theme and vocabulary related to the MOOC, in the target language. 


\subsection{PHASE 1 (First Face-to-Face Class)}

The first phase of the pedagogic sequence, that is, the first face-to-face class has the objective of presenting the teaching proposal, as well as approaching subject matters related to the development of learners' autonomy and their commitment to accomplishing the MOOC activities outside the class within the deadline determined by the teacher. After the introduction of the proposal, an activity is suggested to help learners use online translation tools which may aid the development of reading strategies in English. Activity 1-Reading Strategies in English (Adapted from Finardi \& Porcino, 2013).

Resources-Computers connected to the internet.

Materials - Copies of the activities.

Objective-To use online translation tools to read in English.

\section{Table 1. Activity 1}

Do the activity following the instructions*

Step 1

Look for a piece of news in English about an environmental crime. Type the phrase "environmental crimes or disaster cases - News" in a search site.

Write the title of the news here:

Step 2

Look for a piece of news in your native language about an environmental crime. Type the phrase "environmental crimes or disaster cases-News" in your language in a search site.

Write the title here:

Look for the meanings of the words or phrases you don't know, using the translate.google.com and linguee.com, and write below

Words or phrases in English: Translation in your language:

Note. *All the instructions in the activities should be written in the mother tongue.

In this activity, online translation tools, such as translate.google.com and linguee.com, are introduced to learners and used in the search for definitions of words and expressions in English, as well as the online for Portuguese (Brazilians' native language) dicionariodoaurelio.com, in case learners need to check the meanings of any technical term in Portuguese. In case the teaching project is carried out in a place where the native language is other than Portuguese, adaptations can be made to use dictionaries in the native language of learners, who, together with teachers, may choose other translation tools they consider more convenient. After that, learners work individually or in pairs, in case there are not enough computers for everyone. Learners should choose a piece of news in English about an environmental crime or disaster on the internet, typing "environmental crimes or disaster cases-News", in such a way they access pages with the latest news about environmental crimes around the world. Next, learners select a similar piece of 
news in Portuguese (or their native language), typing "crimes ou desastres ambientais no mundo-notícias" or its equivalent in their native language, so that they may compare both texts, as a means of starting to notice the use of cognates and other lexical and grammatical indicators in their native language and in English to help disambiguate meanings of phrases.

The use of the target language must be prioritized and maximized as much as possible during the activities in face-to-face classes with the purpose of developing the speaking skill whereas listening, reading and writing skills can be developed during the extra class time and during the interaction with the MOOC at home.

One of the principles of the CLIL Approach is the use of the additional language as the vehicular language or instruction language. It is important to highlight that even though the use of the mother tongue during the face-to-face classes may be used as a means of mediating the understanding of the activities, the use of the additional language must be prioritized and, when necessary, calibrated and interspersed with the use of the mother tongue during the discussions about the topics of the MOOC. The use of the mother tongue is important to lower the affective filter, decreasing learner's anxiety, especially when acquainted with new approaches, as demonstrated in some studies (for example Silveira \& Finardi, 2015; Lasagabaster, 2013).

\subsection{PHASE 2 (First Inverted Class)}

The second phase of the pedagogical sequence-which corresponds to the first extra class lesson-has the objective of introducing the vocabulary about the theme to be explored in English. To present the new lexical items, it is recommended a matching activity presented in a power point. The presentation should include the vocabulary and expressions related to the course theme, so that learners may be more familiar with the content in the target language. The vocabulary and expressions should be categorized by topics, followed by their meanings. According to the vocabulary teaching techniques evaluated by Oxford and Crookall (1990), both the fully contextualizing category which involves the practice of vocabulary within a context, and the semicontextualizing category, which allows a certain level of contextualization may be used. In the activity elaborated here the chosen category was the semicontextualizing.

Activity 2-Introduction of words and expressions used in the MOOC topics.

Resources-Computers.

Materials - Copies of the activities in power point sent by email.

Objective-To match lexical items in English with their definitions in students' native language or images.

As an example of the presentation, we used the topic "Population". This way, the words related to this topic should be listed in one column with their explanation in Portuguese (or students' native language) in another column, in the case of more complex expressions, such as resources, doom, starvation, birth rate, death rate and life expectancy. Learners receive the presentation in power point by email and do the activities related to the content vocabulary in the extra class time. 
Table 2. Slide 1-Matching Activity

Match the words in English to their equivalent in Portuguese.
1) Resources
( 3 ) Fome.
2) To be doomed
(1) Recurso, fonte.
3) Starvation
(6) Expectativa de vida.
4) Birth rate
( 2 ) Ser condenado.
5) Death rate
(4) Índice de natalidade.
6) Life expectancy
( 5 ) Índice de mortalidade.

\section{Table 3. Slide 2-Matching Activity}

Match the expressions with their explanations.

( 4 ) A country with a lot of industrial activity and where people

1) In the long/short run

2) Increase/decrease

3) Rise/decline

4) Developed/underdeveloped country

5) To die/to be born generally have high incomes/a country that is less developed economically than most others, with little industry and little money spent on education, health care, etc.

(1) At some time in the future/at a time that is near in the future.

( 5 ) To stop living/when a person or animal is born, they come out of their mother's body and start to exist.

( 2 ) To get bigger or to make something bigger/to become less or to make something become less.

( 3 ) To move up/to reduce in the amount, importance, quality, or strength of something.

The same activity may be elaborated for the topic "Ecosystem", with lexical items such as pasture land, greenhouse gases and fossil fuel and for the topic "Climate Changes", with items such as hurricane, blizzards and thunderstorms, using pictures to demonstrate the meaning of words.

Table 4. Slide 3-Matching Activity

Match the columns.

1) Pasture land

2) Greenhouse gases

3) Fossil fuel
( ) image of Greenhouse gases

( ) image of fossil fuels

( ) image of pastureland 
Table 5. Slide 4-Matching Activity

Match the columns.
1) Hurricane
( ) image of thunderstorm
2) Blizzard
( ) image of blizzard
3) Thunderstorm
( ) image of hurricane

\subsection{PHASE 3 (Second Face-to-Face Class)}

The third phase refers to the second face-to-face class and should be used for an introductory discussion about the content which will be developed throughout the MOOC. This can be possible with the following activity.

Activity 3-Oral and written practice about the context where learners live.

Resources-Computers connected to the internet.

Materials - Copy of the activity.

Objective-Talk in English about the context where learners live in using the vocabulary about sustainability. For this class, we suggest an information exchange activity for learners to talk about the place where they live related to the MOOC topics. In pairs, learners should complete the chart below in the activity copy, using the online dictionaries translate.google.com and linguee.com, when necessary. One learner fills in Part A of the chart, and the other, Part B, using their personal knowledge, or searching in a popular site, for example, in wikipedia.org, or in local official sites. After each learner has filled in their part of the card, they should exchange information, asking questions to one another until they complete the whole table. Dörnyei (2001) argues that the teacher should cultivate motivation by means of strategies, proposing a favorable atmosphere to learning and to group cohesiveness by means of interaction and cooperation among learners. In this sense, the teacher can mediate the oral and written production providing learners with model prompts, such as: "What do you think of this? I think that the most important produce in our state is..." "Do you agree? Yes, definitely. No, I guess that's not the right answer..."“"What's your point of view about this? Well, I'm not sure. Let's check on the internet...".

\section{Table 6. Activity 3}

Complete the table/chart using information about the place where you live. Access the site wikipedia.org or other official local sites. One learner completes Part A and the other completes Part B. After that, change information so as complete the whole chart. Access the online dictionaries translate.google.com and linguee.com, if necessary.

PART A

Population

How many people are there?

What's the population density? 
Ethnicity (people who have the same national,

racial or cultural origins)

Where did the immigrants in your state come

from?

What's the approximate percentage among white,

black and indigenous people in your state?

Ecosystems

What's its geography like?

What's the most important characteristic of its

nature?

PART B

Climate

What's the climate like?

What's the most important river in your state?

Energy

What types of energy are most used (hydropower,

solar, wind, nuclear)?

Agriculture

What are the most important crops in the state?

Are they exported to other countries?

\subsection{PHASE 4 (Second Inverted Class)}

The fourth phase is dedicated to an extra class activity, and, as learners are more familiar with the target vocabulary, we suggest an activity to develop the syntactic knowledge of the additional language.

Activity 4-Written production practice.

Resources-Computers connected to the internet.

Materials-Copy of the activity.

Objective-To produce phrases in the past about environmental crimes or disasters.

\section{Table 7. Activity 4}

Access the sites suggested below and complete the chart, answering the questions about an environmental crime or disaster. Answer the questions using complete sentences in the past. Use the sites translate.google.com and linguee.com to elucidate meanings regarding the text understanding.

Access the site interpol.int/Crime-areas/Environmental-crime/Environmental-crime and answer the questions below.

What kind of Where did it happen? When did it happen? Were there any casualties 
environmental crime

(people killed or injured)?

happened?

Access the site pulitzercenter.org/oceans and complete the chart below.

What kind of unnatural Where did it happen? When did it happen? Were there any casualties? disaster happened?

The activity we chose involves a search on the internet for learners to list an environmental crime or disaster. Learners have to access the recommended sites and choose a subject to describe, answering the questions in the chart above, in such a way that they use the target vocabulary and develop their knowledge of the simple past use in English.

The activity should be emailed to learners, who should send it back to the teacher for verification, after they have accomplished it. In case learners have questions regarding text understanding, they should access the translators translate.google.com and linguee.com, and, in case they have questions regarding the use of the past tense in English, it is advisable that the teacher focuses on this issue in the following face-to-face class.

\subsection{PHASE 5 (Third Face-to-Face Class)}

The fifth phase would be the last face-to-face class before learners start the MOOC. This class should be dedicated to oral production. We suggest a discussion about a subject matter-energy—so as learners can use the vocabulary related to the issue.

Activity 5-Oral production practice.

Resources-White board and markers.

Materials-Copies of Activity.

Objective-To produce oral phrases in English about themes related to the topic "Energy".

\section{Table 8. Activity 5}

Put the words and phrases in order according to its importance to answer the questions below. Use the expressions suggested in the chart footer.

a) What sources of energy are used most commonly to produce energy in your State?

Wind Hydroelectric Coal

Solar Nuclear Natural Gas

b) What sources of energy do you think will be most frequently used in your State in the next 10 years?

Wind Hydroelectric Coal

Solar Nuclear Natural Gas

c) What kinds of transportation fuels do you think are the most appropriate to be used in our State?

Oil Natural Gas Coal 
Electricity (alternative fuel) Ethanol

d) How do you think we can meet our energy needs in the next ten years?

Use wind power Build more nuclear plants

Cut our energy use Use solar power

Build more hydroelectric plants

e) Choose one of the sources of energy and prepare a brief explanation of why it is the best way of meeting our future energy needs.

Expressions you may use

TO MAKE YOUR POINT

1. The point is that...

2. One way to help...

3 . There's no doubt that...

4. The best way to face...

TO AGREE

That's right!

Yes, I agree!

I couldn' agree more!

\section{TO DISAGREE}

I don't agree!

Absolutely not!

That's not right!

Specific vocabulary about energy sources such as: coal, wind power energy, nuclear energy, solar energy, hydroelectric power, oil, should be presented by the teacher using a power point presentation and illustrating with corresponding images to verify learners' knowledge about these words. After that, the teacher hands out the activity. In pairs, students answer each question of the activity, numbering the words and phrases in ascending order according to what they consider more likely. In the chart footer, some expressions are presented so that learners may use as models or prompts during the discussion.

\subsection{PHASE 6 (MOOC and More Three Face-to-Face Classes)}

After having become familiar with the vocabulary and some verbal tenses in the additional language, learners are ready to start the MOOC course. The teacher should reiterate that learners will have other face-to-face classes - three, according to the proposal—in which they will have the opportunity to ask questions about any problem they may have during the MOOC activities, reading and tests. It is important to raise learners' awareness about the fact that the MOOC tests can be retaken, as a means of consolidating knowledge and using the tests as learning opportunity. We suggest some activities that may be explored during the face-to-face classes after learners have started the course.

The fourth face-to-face class should occur during the third and fourth week after the MOOC course begins. We suggest a reading activity with the texts of the MOOC Module 2-Population.

Activity 6-Reading comprehension.

Resources - Computers or cell phones connected to the internet.

Materials-Texts "2006 World Population Data Sheet" (Text 1) and "Transitions in World Population" 
(Text 2).

Objetive-To read a text in English and tell a classmate about it in Portuguese (or learners' native language).

Table 9. Activity 6-Text 1

Read the Text "2006 World Population Data Sheet" and give the required information below to a classmate. Talk about other issues you find important.

Text 1

1. Quais os três países com a maior área sob proteção ambiental e quais os benefícios dessa proteção (What are the three countries with most environmental protection and what are the benefits of this protection?) (Página 1) (Page 1)?

2. Quais os dois países que têm a maior porcentagem de mulheres que não querem ter mais de dois filhos

(What are the two countries with the most percentage of women who do not want to have more than two children?) (Página 1) (Page 1)?

3. Quais os dois países com menos condições de saneamento básico na área urbana (What are the two countries with least sanitation condition in the urban area?) (Página 2) (Page 2)?

\section{Table 10. Activity 5-Text 2}

Read the text "Transitions in World Population" and give required information below to a classmate. Talk about other issues you find important.

Text 2

1. Quais os fatores que contribuíram para a transição demográfica do século $X X$ (What factors contributed to the 20th Century demographic transition?) (Sexto e sétimo parágrafos da página 4) (Sixth and seventh paragraph of page 4$)$ ?

2. Como podemos comparar o crescimento populacional entre os países desenvolvidos e os países em desenvolvimento (How can we compare the populational growth between developed and underdeveloped countries?) (Gráfico da página 5) (Graph of page 5)?

3. Quais as razões mostradas para o declínio da fertilidade (What are the reasons for fertility decline?) (Primeiro e segundo parágrafos da página 7) (First and second paragraphs of page 7)?

The teacher then divides the class in two groups, each one reading one text. The teacher explains that they should browse through the text, and answer the questions in Cards A and B, shown above, taking notes of other issues they may consider important, and using, when necessary, the online translators translate.google.com and linguee.com. The teacher should emphasize the importance of reading and interpreting images, graphs and tables. After the stipulated time for reading, learners are organized in pairs so as each pair contains one learner who reads Text 1 and one who reads Text 2 . The pairs should 
exchange information about the texts they read using their native language, interspersed, when possible, with English, using the questions of the card as a guide.

The fifth face-to-face class should occur between weeks seven and eight after the MOOC course begins.

For this class, we suggest an oral comprehension activity with the video "Oil" of Module 4-Energy.

Activity 7-Oral comprehension.

Resources - Computer or a television with a DVD player.

Materials-Copy of activities.

Objective-To watch and listen to a video in English to answer comprehension questions.

\section{Table 11. Activity 7}

Watch the video of the MOOC Module 4 and fill in the blanks.

Card A

\section{Card B}

I'm Jonathan Tomkin from the University of

I'm Jonathan Tomkin from the University of Illinois.

Illinois. This week we're going to start with a This week we're going to start with a question. Are question. Are 1. a sustainable source of energy? For a long time, they're a leading source of light in American homes. This is why whales 2.__can be rendered down into an oil that provides a clear, bright light. So oil prospecting in the nineteen century was a really tough job. You needed a really big 3 .__ and a really sharp stick. These boats would go out for months, even years at a time, hunt whales, and render them on the decks. This production of oil is in some ways 4.__. Because whales reproduce. However, just as we saw in the fisheries example, it's possible you could over harvest whales and thereby 5 . whales a sustainable source of energy? For a long time, they're a leading 1 . of light in American homes. This is why whales blubber can be rendered down into an oil that provides a clear, bright light. So oil 2.__ in the nineteen century was a really tough job. You needed a really big boat and a really sharp stick. These boats would go out for months, even 3. a a a time, hunt whales, and render them on the decks. This production of oil is in some ways renewable. Because whales 4._. However, just as we saw in the fisheries example, it's possible you could over harvest whales and thereby destroy the resource. And of course today we have 5._issues the resource. And of course today we have moral issues with hunting whales in many countries. Even though oil is, in principle, a renewable 6.__ oil production from whales peaked in the with hunting whales in many countries. Even though oil is, in principle, a renewable resource, oil production from whales 6 . in the 1840s and then

1840 s and then declined.

Source: Adapted from MOOC_Introduction to Sustainability.

Before starting the activity, the teacher should write the following words on the board: whales, source, blubber, render down, prospecting, sharp stick, renewable, over harvest, issues, peak and check learners' 
knowledge of the words. Next, learners should be gathered in pairs, one learner receiving Card A, and the other, Card B. The cards should contain a video excerpt transcription, with some blank spaces.

After playing the beginning of the video - up to the $1 \min 14 \mathrm{sec}$ time - twice without subtitles, learners fill in the blanks. After that, learners check answers with their respective pairs.

The sixth and last face-to-face class of Phase 6 should occur during week ten after the MOOC course begins. This class may involve a written production, according to Module 6-Environmental Policy.

Activity 8-Written production practice.

Resources - White board and markers.

Materials-Copies of activity.

Objective-Write a letter in English reply to an article.

\section{Table 12. Activity 8}

Complete the letter below in reply to a newspaper article, putting the options in the write order.

Dear Sir

Your newspaper recently published an article about the government's plans for water use in this state. I would like to make a few comments.

Firstly, water reserves continue to fall and the water fee is rising all the time. If we want to maintain our comfortable life in the future, then we must find ways to combat this problem. We should make more of an effort to conserve the water reserves we have and to a)

Also, we need to reduce water consumption. One solution to this problem is to invest more money in b) The government must develop c)

Currently, d) If something is not done soon to change this, our society can be seriously affected in the very near future.

I look forward to reading other points of views on this subject.

Yours,

Paul Young

1. reforesting and protecting our water sources

2. industry and agriculture water consumption is really high/too much

3. think of alternative forms of energy

4. a publicity campaign on the appropriate use of water

In this activity, the learner should write parts of a text about necessary environmental policy in the place where he/she lives. After receiving copies of the text above, learners fill in the spaces offering suggestions for solutions to water scarcity. Next, learners gather in groups of three to check their answers according to the options in the chart footer. 


\subsection{PHASE 7 (Seventh Face-to-Face Class)}

Finally, the last phase, which corresponds to the seventh face-to-face class, has the purpose of providing learners with the opportunity to practice their concepts of sustainability as well as their knowledge of new expressions and vocabulary about this theme in English. This can be done with an activity of oral production like the one described below.

Activity 9-Oral production practice about environmental problems, solutions, social agents' responsibilities and obligations.

Resources-Data show.

Materials - Copy of the activity cards.

Objective-To produce phrases orally in English about themes related to sustainability.

Table 13. Activity 9

\begin{tabular}{lll}
\hline Card A & Card B & Card C \\
\hline 1. Famine & 1. Should build houses in solid soil. & 1. The government \\
2. Flood & 2. Must distribute food. & 2. The population \\
3. Drought & 3. May provide health care and medicine. & 3. Schools \\
4. Disease & 4. Has to offer potable water. & 4. Companies \\
\hline
\end{tabular}

The suggested activity is divided in four different moments. First, the teacher presents the content in the cards in the data show to check learners' possible questions regarding the pronunciation and/or meaning of words. After that, the teacher invites learners to work in pairs. The teacher hands out Cards A, B, and C to each pair and explains the activity. Each pair receives three cards. Card A contains four expressions about environmental problems, Card B contains solutions to the problems and Card C contains possible responsible agents for the solution to the problem.

Learner 1 holds Card A and talks about an environmental problem. Learner 2, using Cards B and C, presents possible solutions and responsible agents to the problem. We suggest that learners read the cards, however, when interacting in English, we suggest they try not to look at the cards so that they can formulate oral productions in a natural way, which is different from the way they formulate sentences when they read.

\section{Conclusion}

The aim of this paper was to reflect about possibilities and limitations of hybrid approaches to the teaching of additional languages. With that aim, the study reviewed some current teaching approaches that may be used in the hybrid approach and elaborated a teaching project based on the Inverted CLIL (Finardi, 2015) approach to teach the content of sustainability through English as an additional language. The purpose of the elaboration of the teaching plan described here is to serve as an example of a possible 
application of the Inverted CLIL approach to feed teacher decision making. Results of the analysis of the Inverted CLIL approach carried out during the review of the literature and the elaboration of the teaching plan based on this approach suggest that the Inverted CLIL approach may be used to mitigate the following problems faced in traditional approaches: 1) lack of time to teach contents or the additional language in school curricula, 2) lack of motivation by learners once they do not see many applications for the contents they learn or the language they learn in isolation, 3) lack of learner engagement once learners are responsible for most of the learning process in this approach, 4) lack of access to education online through MOOCs delivered in languages other than English (Finardi \& Tyler, 2015), 5) respect for teachers' and learners' teaching/learning styles and needs.

\section{References}

Alencar, J. G. C. (2016). Abordagem de Ensino de Língua Inglesa por Meio de Conteúdos e Formação de Professores: Apropriações, Possibilidades e Limitações (213f.) (Unpublished Master Dissertation). Graduate Program of Education (PPGE) of the Federal University of Espirito Santo, Vitoria, Brazil.

Brown, H. D. (2001). Teaching by principles: An interactive approach to language pedagogy. San Francisco: Longman.

Coyle, D., Hood, P., \& Marsh, D. (2010). Content and language integrated learning. Ernst Klett Sprachen.

Dias, R., Pimenta, S., \& M., O. (2015). Technologies, literacies in English oral communication and teacher education: An empirical study at the university level. Revista Brasileira de LinguísticaAplicada, 15(3), 711-733. http://dx.doi.org/10.1590/1984-639820156305

Dornyei, Z. (2001). Motivational strategies in the language classroom. Cambridge: Cambridge University Press. http://dx.doi.org/10.1017/CBO9780511667343

Fadini, K., \& Finardi, K. R. (2015a). Web 2.0 Tools for the L2 Class and beyond. In END2015-International Conference on Education and New Developments, 2015, Porto (Vol. 1, pp. 603-607). Lisbon: World Institute for Advanced Research and Science (WIARS).

Fadini, K., \& Finardi, K. R. (2015b). Affordances of web 2.0 interfaces for the teaching/learning of L2 in the flipped classroom. In International Conference of Education, Research and Innovation, 2015, Sevilha (Vol. 1, pp. 1052-1058). ICERI 2015 Proceedings. Madri: Iated.

Finardi, K. R. (2012). Technology and L2 learning: Hybridizing the curriculum. In M. S. Beck, R. Silveira, S. B. Funk, \& R. P. Xavier (Orgs.), Language and Literature in the Age of Technology-III CongressoInternacional ABRAPUI. Anais...Universidade Federal de Santa Catarina (Vol. 1, pp. 1-8). Florianópolis: Universidade Federal de SantaCatarina.

Finardi, K. R. (2014). The Slaughter of Kachru's Five Sacred Cows in Brazil: Affordances of the Use of English as an International Language. Studies in English Language Teaching, 2, 401-411.

Finardi, K. R. (2015). Current Trends in ELT and Affordances of the Inverted CLIL Approach. Studies in English Language Teaching, 3, 326-338. 
Finardi, K. R. (in press). What Brazil can learn from Multilingual Switzerland and its use of English as a Multilingua Franca. Revista Acta Scientiarium.

Finardi, K. R., \& Archanjo, R. (2015). Reflections of Internationalization of Education in Brazil. In 2015 International Business and Education Conference, 2015, Nova Iorque (Vol. 1. pp. 504-510). 2015 International Business and Education Conference Proceedings. Nova Iorque: Clute Institute.

Finardi, K. R., \& Csillagh, V. (2016). Globalization and linguistic diversity in Switzerland: Insights from the roles of national languages and English as a foreign language. In S. Grucza, M. Olpinska, \& P. Romanowski (Orgs.), Advances in Understanding Multilingualism (1st ed., Vol. 24, pp. 41-56). Warsaw: Peter Lang GmbH, International Academic Publishers. Frankfurt am Main.

Finardi, K. R., \& Dalvi, M. A. (2013). Crenças de professores de línguas sobre a formação inicial e continuada. Glauks (UFV), 13, 113-134.

Finardi, K. R., \& Pimentel, B. (2013). Crenças de professores de inglês sobre o uso do Facebook. Revista (Con) Textos Linguísticos (UFES), 7, 238-253.

Finardi, K. R., \& Porcino, M. C. (2013). Internet tools in the design of a task cycle for L2 teaching. Revista Contextos Linguísticos, 7, 273-291.

Finardi, K. R., \& Porcino, M. C. (2014). Tecnologia e Metodologia no Ensino de Inglês: Impactos da Globalização e da Internacionalização. Ilha do Desterro, 66, 239-284. http://dx.doi.org/10.5007/2175-8026.2014n66p239

Finardi, K. R., \& Porcino, M. C. (2015). O papel do inglês na formação e na internacionalização da educação no Brasil. Revista horizontes de Linguística Aplicada, 14, 109-134.

Finardi, K. R., \& Porcino, M. C. (2016). Facebook na ensinagem de inglês como língua adicional. In J. Araújo, \& V. Leffa (Orgs.), Redes sociais e ensino de língua: O que temos de aprender (pp. 99-115). Parábola Editorial, São Paulo.

Finardi, K. R., \& Prebianca, G. (2014). Políticas linguísticas, internacionalização, novas tecnologias e formação docente: Um estudo de caso sobre o curso de Letras Inglês em uma universidade federal. Leitura (UFAL), 1, 129-154.

Finardi, K. R., \& Tyler, J. (2015). The Role of English and Technology in the Internationalization of Education: Insights from the Analysis of MOOCs. In 7th International Conference on Education and New Learning Technologies. Proceedings (Vol. 1, pp. 11-18). Barcelona: IATED.

Finardi, K. R., \& Vieira, G. V. (2016). Ensino Crítico de Inglês e Formação Docente na Contemporaneidade. Atos de Pesquisa em Educação, 11(2), 549-571. http://dx.doi.org/10.7867/1809-0354.2016v11n2p549-571

Finardi, K. R., Covre, J. M., Santos, L. B., Peruzzo, S. P., \& Junior, C. A. H. (2013). Facebook as a tool for L2 practice. Revista (Con) Textos Linguísticos (UFES), 7, 312-325.

Finardi, K. R., Prebianca, G., \& Momm, C. (2013). Tecnologia na Educação: O caso da Internet e do Inglês como Linguagens de Inclusão. Revista Cadernos do IL, 46, 193-208.

Finardi, K. R., Prebianca, G., \& Schmmit, J. (2016). English Distance Learning: Possibilities and Published by SCHOLINK INC 
Limitations of MEO for the Flipped Classroom. Revista Brasileira de Linguística Aplicada, 16, 181-208. http://dx.doi.org/10.1590/1984-639820158527

Finardi, K. R., Silveira, N., \& Alencar, J. G. (2016). First Aid and Waves in English as a Foreign Language: Insights from CLIL in Brazil. The Eletronic Journal of Science Education, 2, 11-30.

Finardi, K. R., Teixeira, D., Prebianca, G. V. V., \& Dos Santos Junior, V. P. (2014). Information Technology and Communication in Education: Two Sides of the Coin in Brazil. International Journal of Recent Contributions from Engineering, Science \& IT (iJES), 2, 21-25. http://dx.doi.org/10.3991/ijes.v2i2.3814

Finardi, K., \& Veronez, T. (2013). Beliefs on the Use of Facebook as a Communication Tool between Teachers and Students. Revista (Con) TextosLinguísticos (UFES), 7, 292-311.

Franco, C. P. (2010). A tecnologia no ensino de línguas: Do século XVI ao XXI. Letra Magna, 6, 18.

Graddol, D. (2006). English Next: Why global English may mean the end of "English as a foreign language” (p. 132). The English Company (UK) Ltd. British Council. Retrieved from http://www.britishcouncil.org/learning-research-english-next.pdf

Graham, C. R. (2006). Blended Learning Systems: Definition, Current Trends, Future Directions. In C. J. Bonk, \& C. R. Graham (Eds.), Handbook of Blended Learning: Global perspectives, local designs (pp. 41-54). San Francisco, CA: Pfeiffer Publishing.

Graham, C. R., Allen, S., \& Ure, D. (2005). Benefits and Challenges of Blended Learning Environments. In Encyclopedia of Information Science and Technology, First Edition (pp. 253-259). IGI Global. http://dx.doi.org/10.4018/978-1-59140-553-5.ch047

Lage, M. J., Platt, G. J., \& Treglia, M. (2000). Inverting the classroom: A gateway to creating an inclusive learning environment. The Journal of Economic Education, 31(1), 30-43. http://dx.doi.org/10.1080/00220480009596759

Larsen-freeman, D. (2000). Techniques and Principles in Language Teaching. Oxford: O.U.P.

Lasagabaster, D. (2013). The use of the L1 in CLIL classes: The teachers' perspective. Latin American Journal of Content and Language Integrated Learning, 6, 1-21. http://dx.doi.org/10.5294/laclil.2013.6.2.1

Leffa, V. J. (2016). Redes sociais: Ensinando línguas como antigamente. In J. Araújo, \& V. J. Leffa (Eds.), Redes sociais e ensino de línguas: O que temos de aprender (pp. 143-159). São Paulo: Parábola.

Levy, P. (1999). Cibercultura. São Paulo.

Ortiz, R. A., \& Finardi, K. R. (2015). Social Inclusion CLIL: Evidence from La Roseraie. In International Conference on Education, Research and Innovation 2015, Sevilha. ICERI2015 Proceedings (Vol. 1, pp. 7660-7666). Madri: Iated.

Oxford, R., \& Crookall, D. (1990). Vocabulary learning: A critical analysis of techniques. TESL. Canada Journal, 7(2), 9-30. http://dx.doi.org/10.18806/tesl.v7i2.566

Paiva, V. L. M. O. (In press). O uso da tecnologia no ensino de línguas estrangeiras: Breve retrospectiva Published by SCHOLINK INC. 
histórica. Retrieved from http://www.veramenezes.com/techist.pdf

Pinheiro, L. M. S., \& Finardi, K. R. (2014). Políticas públicas de internacionalização e o papel do inglês: Evidências dos programas CSF e ISF. In II Conel, 2014, Vitória. Anais do II Conel (Vol. 1, pp. 76-78). Vitória: PPGEL.

Porcino, M. C., \& Finardi, K. R. (2014). Globalization and internationalization in ELT: Methodology, technology and language policy at a crossword in Brazil. In International Conference of Education, Research and Innovation, 2014, Sevilha. ICERI2014 Proceedings (Vol. 1, pp. 1-11). Madri: IATED.

Porcino, M. C., \& Finardi, K. R. (2015). Webquests para a ensinagem de inglês: Análises e contribuições. In J. B. B. Junior (Org.), Metodologia WebQuest na Educação: Teoria e práticas pedagógicas (1st ed., pp. 171-202). Rio de Janeiro: Publit Soluções Editoriais.

Porcino, M. C., \& Finardi, K. R. (2016). Construção de cidadania por meio do ensino de língua estrangeira e do letramento digital: Uma proposta de WebQuest. Antares: Letras e Humanidades, 8 , 144-166.

Prebianca, G., Cardoso, G. L., \& Finardi, K. R. (2014). Hibridizando a Educação e o Ensino de Inglês: Questões de inclusão e qualidade. Revista do GEL, 11, 47-70.

Prebianca, G., Finardi, K. R., \& Cardoso, G. L. (2015). Ensino-aprendizagem em contextos híbridos: O que pensam os alunos sobre o uso da tecnologia em aulas de inglês no Ensino Médio Integrado. Caminhos em Linguística Aplicada, 12, 95-119.

Rabello, C. (2015). Interação e aprendizagem em Sites de Redes Sociais: Uma análise a partir das concepções sócio-históricas de Vygostky e Bakhtin. Revista Brasileira de Linguística Aplicada, 15(3), 735-760. http://dx.doi.org/10.1590/1984-639820156288

Rada, J. (2004). Oportunidades e riscos das novas tecnologias para a educação. In J. Tedesco (Ed.), Educação e novas tecnologias: Esperança ou incertezas (pp. 109-119)? Unesco: Cortez Editora.

Santos, C. G. (2013). Reflexões a cerca do ensino baseado em tarefas como aporte teórico para a metodologia Webquest. Revista (Con)textos Linguísticos, 7, 62-78.

Sharam, P., \& Barrett, B. (2007). Blended Learning: Using technology inside and beyond the language classroom. Oxford: Macmillan Publishers Limited.

Silveira, N. (2015). Hibridizando o ensino de inglês na Escola de Aprendizes-Marinheiros do Espírito Santo. Master Dissertation in Applied Linguistics. Federal University of Espirito Santo, Vitoria, Brazil.

Silveira, N., \& Finardi, K. R. (2015). Hybridizing L2 Learning: Insights from an Intact Class Experience. In END 2015-International Conference on Education and New Developments, Porto (Vol. 1, p. 593). END 2015 International Conference on Education and New Developments Proceedings. Lisbon: World Institute for Advanced Research and Science (WIARS).

Tedesco, J. C. (2012). Educacion, Tecnologia y Justicia Social en la Sociedad del Conocimiento. Revista Científica e-Curriculum, 10(3), 6-30.

Teixeira, D., \& Finardi, K. R. (2013). Tics no ensino presencial: Evidências de um curso deformação 
continuada na Universidade Federal do Espírito Santo. Revista (Con)textosLinguísticos (UFES), 7, 79-96.

Tilio, R. (2014). Língua Estrangeira Moderna na Escola Pública: Possibilidades e desafios. Educação \& Realidade, Porto Alegre, 39(3), 925-944. Retrieved June 20, 2016, from http://www.ufrgs.br/edu_realidade

Wagner, R., Piovesan, S., Passerino, L., De Lima, J. V., \& Lozano, C. De C. (2015). MOOCs of Inclusive Technology in Teacher Education for Vocational Education. Creative Education, 6, 1832-1840. $\begin{array}{llll}\text { Retrieved } & \text { October } & 18, & \text { 2015, }\end{array}$ http://www.scirp.org/journal/PaperInformation.aspx?paperID=60242

Warschauer, M. (2002). Reconceptualizing the digital divide. First Monday, 7(7). Retrieved October 20, 2015, from http://www.firstmonday.org/ojs/index.php/fm/article/view/967/888.\#w4

Warschauer, M. (2003). Social capital and access. Universal access in the Information Society, 2(4), 315-330. http://dx.doi.org/10.1007/s10209-002-0040-8

\section{Notes}

Note 1. https://www.coursera.org

Note 2. Retrieved January, 2016, from https://www.coursera.org/learn/sustainability

Note 3. In Portugueses Exame Nacional do Ensino Médio (High School National Exam). 